\title{
Root Rot Diseases in Plants: A Review of Common Causal Agents and Management Strategies
}

\author{
Eliane Thaines Bodah ${ }^{1 *}$ \\ Department of Biostatistics, University of Washington, USA
}

Submission: February 17, 2017; Published: March 27, 2017

"Corresponding author: Eliane Thaines Bodah, Department of Biostatistics, University of Washington, Seattle WA 98195, USA, Tel +1-315-4168882; Email: elianeb@uw.edu

\begin{abstract}
Root rot is a serious threat to agriculture worldwide, continuously reducing yields and jeopardizing crop survival. Depending on the causal agent, host susceptibility, and the environmental conditions, entire fields can be lost to this disease. In this review work, we present the following root rot causal pathogens: bacteria, virus, oomycetes, and fungi. Bacterial and viral root rots are less common and not many studies have reported these causal agents. Oomycetes and fungi have been found to be the most commonly widespread root rot pathogens. Reported oomycetes are Aphanomyces spp., Pythium spp., and Phytophthora spp. Several fungi were reported to cause root rot, including, Rhizoctonia spp., Fusarium spp. and Phoma spp., Aphanomyceseuteiches and Thielaviopsisbasicola. These diseases are highly influenced by the environment, with a broad range of hosts, hidden underground symptoms and overwinter structures of many root rot pathogens, disease control and management are very complex and hard to achieve. Chemical treatment is generally only available as preventive seed treatment. Chemical treatment is generally only available as preventive seed treatments. Chemicals are also used as a way to kill the green bridge between crops. Overall, despite the complexity of this trait, resistance to root rot through enhanced varieties is the biggest promise to control such devastating diseases.
\end{abstract}

Keywords: Root rot; Plant-microbe interactions; Diseases management

\section{Introduction}

Root rot pathogens cause some of the most important plant diseases worldwide impacting several crops [1,2]. Root rot symptoms are a major threat because the damage starts below the ground, where the first symptoms are not discernible. When the symptoms become apparent on the above ground part of the plant, yield is already compromised and plant survival is jeopardized.

Several pathogens can cause root rot, some are hostspecific and some have a broader range of hosts. Reported root rot pathogens can belong to different groups such as bacteria [3] virus [4], oomycetes [5] and fungi [6-8]. In addition, root nematodes and other parasites play a role in facilitating root rot by wounding the plant and enabling the entrance of other pathogens. Fungi are the most abundant causal agents of root rot and they can stay dormant and overwinter in debris and infested soil for several years [9].

Some of the symptoms associated with root rot are browning and softening of root tips, root lesions that vary in size and colorfrom reddish to brown and black, trimming of the root and decay, yellowing and wilting of leaves, stunted plant growth, reduced yield and loss of crop [10-12].

The progression and success of infection depends on the disease triangle, which comprises the host-pathogenenvironment interactions. Root rot is highly influenced by the environment and is favored by: moderate to high soil moisture, optimal temperature for pathogen growth, soil compaction, poor drainage, continuous or frequent cropping and other factors that contribute to plant stress $[13,14]$. This review presents a comprehensive overview of different groups of root rot agents in plants, along with alternative methods and strategies to manage and prevent root rot diseases.

\section{Bacterial and Viral Root Rots}

Bacterial root rot is not very common but it can be devastating to fruit, vegetable and ornamental plant production. Often, the bacteria gain entry into the host via a wound. Storage organs such as tubers are the preferred site of entry and the damage progresses rapidly beyond the roots. The soft rot caused by the members of Enterobacteriaceae is a good example of 
generalized damage. Two genera in this group, Pectobacterium and Dickeya, with a wide range of pathogenic species, cause wilt and rot diseases on monocot and dicot plant hosts worldwide. These bacterial pathogens secrete high amounts of plant-cellwall-degrading pectinases and polygalacturonases which digest plant cell walls and cause soft rot symptoms [15].

Within the Pectobacterium genera, an economically important pathogen is $P$. betavasculorum which has been reported to cause bacterial vascular necrosis and root rot of sugar beet. Within the Dickeya genera, Erwinia chrysanthemi is an economically important pathogen because it causes bacterial stem and root rot of sweet potato [16]. This pathogen causes soft rot disease in a wide range of crops in mild climate regions and in greenhouse settings [17].

Bacterial stem and root rot is common in storage but may also affect plants in the field and in seedbeds. The first symptom is the partial wilting of the plant and eventually the entire plant may collapse and die. Water-soaked, sunken brown to black lesions are observed at the base of stems and on petioles. On fibrous roots, localized lesions are observed, but the entire root system can be affected, showing the characteristic black, watersoaked appearance. Dark streaking in the vascular tissue of the roots has also been reported [18].

Viral root rots are less common than bacterial root rots. Some studies have reported cassava brown streak virus as a causal agent of root necrosis. Two distinct virus species have been identified, cassava brown streak virus and Ugandan cassava brown streak virus. Both are members of the Potyviridae family and are transmitted by the whitefly vector Bemisia tabaci (Gennadius). Dissemination of the virus is through cuttings that are taken from infected parent material [19]. As detection methods evolve, information regarding the non-traditional causative agents of root rot is expected to increase.

\section{Oomycetes}

Oomycetes, also known as water molds, are a large group of terrestrial and aquatic eukaryotic organisms that superficially resemble fungi in mycelial growth and mode of nutrition. However, molecular studies and distinct morphological characteristics have placed them in the kingdom Chromalveolata, phylum Heterokontophyta [5]. The terrestrial oomycetes are primarily parasites of vascular plants, and include several important root pathogens such as Aphanomyces spp., Pythium spp., and Phytophthora spp.

Among the Aphanomyces spp. A. cochlioides creates a major constraint in cultivation of sugar beet, causing damping off and chronic root rot $[13,20]$. Another economically important root pathogen in this group is A. euteiches infecting a variety of field crops worldwide, especially legumes. This pathogen can drastically reduce yield in beans [21], alfalfa [22], fava beans [23], clover, lentils and peas [24,25].
For instance, A. euteiches Drech., is responsible for one of the most damaging soil-borne root diseases in peas worldwide [26]. It can affect the plant at any developmental stage, causing rotting of the roots and epicotyls that result in stunted seedlings, yellow leaves and even dead plants [27]. The development of cultivars with tolerance or partial resistance to Aphanomyces root rot is generally considered to be one of the best options to reduce yield loss [25]. Resistance is limited in commercial cultivars [27]. Cultural practices for Aphanomyces root rot are highly dependent on environmental conditions, mainly because proliferation is through water-motile zoospores that thrive in poorly drained soil conditions [28].

Pythium, with over two hundred described species, can cause a variety of diseases including root rot in numerous plant hosts [29]. At least ten Pythium spp. cause Pythium damping off and root rot in various legumes and monocots.A rapid black rot of the entire primary root that can move up to the stem is typical of this pathogen. P. ultimum and P. irregular have been reported as the most ubiquitous pathogens in this group [30].

Root rot caused by Pythium spp. is one of the most damaging diseases restricting production of common bean [31]. This disease in corn was reported to be caused by P. graminicola in Japan. Tobacco seedlings in floating systems were also infected by $P$. diclinum [32]. Ornamentals under different irrigation regimes were reported to be infected by $P$. aphanidermatum and P. ultimum [33]. These same two species were shown to infest greenhouse cucumber production [34]. Some other specialty crops such as parsnip and parsley have up to $80 \%$ and $100 \%$ yield losses in Australia which is attributed to Pythium [35]. P. arrhenomanes is considered to be the most important cause of sugar-cane root rot [36]. Pythium root rot is also a relevant disease for wheat [37] and common bean.

Phytophthora spp. belong to the family Pythiaceae along with Pythium spp. and together they attack a wide range of woody ornamentals as well as annual crops. Symptoms include wilting, yellow or sparse foliage and branch dieback. Phytophthora spp. cause late blight of potato and tomato, foliar blights on peppers and cucurbits, and root or stem rots of many plant species. Taiwan cherry was reported to be infected by P. cambivora. Root rot of pea and fava bean in Southern Sweden were found to be caused by P. pisi sp. nov. [38]. The P. citricola complex has been found associated with mortality of Aucuba japonica in the UK [39]. P. palmivora is a common causal agent in papaya root rot [40]. Phytophthora root rot is also a threat to red raspberries [41], chickpeas [42,43], pepper [44], soybean [45], ash trees [46], kiwi fruit [47], avocado [48], and innumerous other crops.

\section{Fungal Root Rots}

There are several fungal root rot pathogens that compromise root health. For conifers, Heterobasidion annosum sensulato, Armillaria ostoyae, and Phellinus sulphurascens are important fungal pathogens causing annosum, armillaria and laminated 
root rot, respectivelly. These pathogens are found in temperate forests of the northern hemisphere causing decay, growth reduction and tree mortality [6].

Annosum root rot caused by Heterobasidion spp is common in plantation-grown conifers [49]. The H. annosum species complex consists of five species. Three of the species $H$. annosum, H. parviporum and H. abietinum, occur in Europe, and the other two $H$. irregulare and $H$. occidentale occur in North America, [13]. H. parviporum can increase drought stress while infecting the roots in Norway spruce in the Alps [50]. Infected trees often show no above ground symptoms until survival is compromised. Infected roots have lesions that can spread to other organs [51].

Armillaria root rot is caused by Armillaria spp. infecting oaks and other woody ornamental and crop trees and shrubs [52]. Root rot caused by A. cepistipes correlates positively with dieback severity and plays a role in tree decline. It was observed that even four years after tree falling, root rot was found to have a negative impact on sprouting efficiency [53]. A. mellea is an important phytopathological problem in the wine sector [54]. In the vineyard it reduces plant vigor, causes chlorotic leaves to develop, and hastens phylloptosis in autumn [55]. Armillaria root rot is also a threat to apple, walnut and kiwi production [56].

Laminated root rot is the most damaging disease of younggrowth Douglas-fir and other conifers in the Pacific Northwest region of the U.S. This disease is caused by the fungus Phellinus weirii, which survives for 50 years or more in roots after trees are harvested [57]. Phellinus sulphurascens is also a major naturally occurring pathogenic fungus. The disease spreads below ground at root contact regions and often occurs in combination to Armillaria root rot [6]. Laminated root rot also been reported to be caused by Phellinidium qilianense in qilian juniper [7].

Another important tree root disease is the white root rot caused by the ascomycete Rosellinia necatrix, attacking a wide range of perennial plants [58]. White root rot is the major threat to apple in Kashmir valley. The moist conditions of the orchards and deficient irrigation system create the right conditions for this disease [59]. This pathogen is also a serious problem for avocado production in the Mediterranean [60]. Symptoms include root and collar rot of trees leading to a decline in vigor. A distinct margin is usually visible between the infected and healthy bark with a thin layer of white fungal growth found under the diseased bark. A white cottony mycelium and mycelia strands, either white or black, appear on and surrounding infected roots or inside the bark [61].

Rhizoctonia root rot is a frequent disease of many crops such as bean [62], apple [63], tobacco, blueberry [64], tomato [65], pea [66], and canola [67]. This pathogen generally attacks its hosts in the juvenile stages of development. Rhizoctonia root and crown rot, caused by $R$. solani, is the most widespread and damaging sugar beet disease in Nebraska [68]. Rhizoctonia root rot and bare-patch are diseases that limit the yield of direct- seeded cereals, especially wheat and barley [69]. R. bataticola is another serious threat mainly in cotton production [70].

Fusarium root rot is a common disease in several crops. Symptoms include round or irregular light brown lesions that progress to dark black lesions on below ground roots and stems, stunting and death [71]. In legumes, the major root rot causing agents are F. solani and F. avenaceum [72]. Thus, production of bean [73], soybean [74], pea [75], lentil [76], and peanut [77] is highly compromised by this type of pathogen. F. solani can cause severe rot in sweet potato roots [78] and cassava [79]. Fusarium spp. also cause other rots such as Fusarium crown rot in cereals and Fusarium stalk (stem) rot in corn. These species differ from those responsible for disease in dicots and include: F. graminearum, F. culmorum, F. avenaceum, F. verticillioides, and F. Pseudograminearum. F. culmorum causes foot and root rot and Fusarium head blight on different small-grain cereals, particularly wheat and barley [80]. F. graminearum plays a role in crown and root diseases of wheat. F. chlamydosporum infects coleus and other ornamentals. F. oxysporum is more frequently associated to wilt but it causes root rot on members of the Cactaceae family such as Schlumbergera truncate [81]. F. oxysporum also causes stem and root rot in melons [82].

Phoma root rot is caused by many species. P. betae is known to cause leaf spot and rotting of beets during storage. P. terrestris has been reported to cause pink root rot of onion [83]. Red root rot of corn is also attributed to P. terrestris [84]. Roots and basal stalk tissue infected with red root rot have a reddish pink discoloration that becomes a deeper red color as the disease progresses [85]. P. sclerotioides causes brown root rot of alfalfa and other perennial forage legumes [86].

Black root rot is primarily caused by Thielaviopsisbasicola. It infects a wide range of hosts, causing root disease in over 200 plant species. Symptoms include stem rot and damping off in some hosts in addition to rotten roots. Economically important hosts are tobacco [87], carrot [88], cotton [89], and soybean [90].

There are several other root rot pathogens that are less frequently reported. Some examples of such pathogens include Aspergillus spp., Alternaria spp., Curvularia spp., Rhizopus spp. and Penicillium spp., isolated from soil, root, stem and foliar samples of plants showing root rot symptoms [91]. Fungi Rigidoporus lignosus and Phellinus noxius are root rot pathogens reported in rubber trees. Dry root rot of chickpea caused by Macrophomina phaseolina is another significant fungal root disease that impacts chickpea production areas in India [92].

Overall, root rots are generally referred to as a complex, for example, black root rot of strawberry is attributed to Pythium, Fusarium, and Rhizoctonia pathogens [93]. Another example is the pea root rot complex where the disease is caused by a single pathogen or a combination of pathogens, including Alternaria alternata, A. euteiches, F. oxysporum, Fsolani, F. avenaceum, Mycosphaerella pinodes, Pythium spp., R. solani, 
Sclerotiniasclerotiorum and Phytophthora spp. [94,95]. Other fungi that can be associated with pea root rots include $T$. basicola and Ascochytapinodella. Phoma spp. can also be referred as part of the pea root rot complex [96].

\section{Management Strategies for Root Rot}

Effective management of root rot can be achieved by adopting resistant and tolerant varieties. Cultural practices, chemical treatments and biological control agents are also extremely important. Cultural practices can directly or indirectly affect populations of soil borne pathogens and the severity of their resultant root diseases [97].

Draining wet soils, crop rotation, soil preparation by tillage, fertilization, and weed control before planting have been reported as tools to manage root rot diseases. Planting within the recommended seed rate to avoid overcrowding can also decrease disease pressure. Crop rotation can break the disease cycle and affect soil chemistry. Many species within the Brassicaceae family contain glucosinolates that liberate products such as the volatile isothiocyanates, shown to suppress $A$. euteiches through hydrolysis. In this sense, Brassicaceae seed meal applications can also be used for its fungicidal benefits.

Reducing the green bridge by killing weeds or volunteer plants that allow the fungus to survive between crops is another important cultural practice. This control can be achieved by using herbicides such as glyphosate to control Rhizoctonia root rot in wheat [98]. However, fungal pathogens can survive for many years in soil as mycelium and by producing sclerotia. This increases the complexity of management, potentially mandating the application of bio control agents. Chemical treatment after planting is not a common option to treat root rots due to the advanced state of the disease by the time above ground damage is evident.

Other options for preventing root rot can include the use of chemical fungicides, inoculation or bio control agents. For instance, the population density of $R$. solani was reduced significantly in the rhizosphere of pea seedlings obtained from seeds pretreated with Trichoderma and/or Topsin-M. Treatment with Apron XL+Maxim4 FS+Cruiser with or without Rhizobium inoculant increased emergence and reduced root rot severity and the number of Pythium colonies compared to the untreated control.

Integrated pest management is more applicable, including timely fungicide applications, crop rotation and attention to soil moisture levels, along with developments in bio control. Plant growth-promoting rhizobacteria such as Bacillus pumilus and Pseudomonas putida, along with antagonistic fungi such as Aspergillus awamori, Aspergillus niger and Trichoderma harzianum have been used to control Fusarium root rot of pea [99]. Integration of soil application and seed treatment formulations of Trichoderma spp. for management of wet root rot of mungbean caused by $R$. solani has also been reported [100].
Strains of Pseudomona spp. have been shown to reduced disease symptoms of both $R$. solani AG-8 and P. ultimum, and the latter four also suppressed $R$. oryzae and $P$. irregular [101]. Studies on cultures of P. cinnamomi exposed to different $\mathrm{Ca} 2+$ fertilizers in vitro showed significant inhibition of sporangial, chlamydospore and zoospore production at millimolar concentrations while mycelial growth was mainly unaffected [102]. Trichoderma viride and Pseudomonas fluorescens were successfully used when combined as biocontrol agents for dry root rot of chickpeas.

Other alternative treatments are recently being considered, including soil type studies. Sandy soil covered with consortium of Zea mays and Vignaunguiculata was efficient in suppressiveness against disease caused by F. solani in cassava root rot. Vermicomposting for organic production was effective to reduce root rot in a complex disease of Coleus forskohlii involving Fusarium chlamydosporum and Ralstoniasolanacearum, in terms of $73 \%$ percent less wilt incidence and $82 \%$ less severity of root rot.

One pathogen may also inhibit another pathogen. For example, in a study conducted with alfalfa, co-inoculation with both A. euteiches and Phytophthoramedicaginis resulted in significantly reduced amounts of P. medicaginis DNA detected when compared with amounts detected from inoculations with P. medicaginis alone [103].

Resistance for root rot diseases is generally imparted by more than one gene and is referred to as quantitative resistance. This type of resistance provides partial and durable resistance to a range of pathogen species in different crops [104]. Root rot resistance is often quantitative. Most of the genes underlying this trait are difficult to introgress in modern-type cultivars while maintaining field and market desirable agronomic and quality traits.

\section{Applying genetics to improve resistance}

Identification of quantitative trait loci (QTL) in carefully designed genetic studies has been a major approach to study quantitative resistance. QTL studies are used to understand: epistatic and environmental interactions, race-specificity of partial resistance loci, interactions between pathogen biology, plant development and biochemistry, and the relationship between qualitative and quantitative loci. QTL mapping also opens up the possibility of positional cloning of partial resistance genes and its subsequent use in marker-assisted selection (MAS) of complex disease resistance characters [105]. MAS is the process of using morphological, biochemical, or DNA markers as indirect criteria for selecting agriculturally important traits in crop breeding [106].

Conventional plant breeding and genetic engineering are known to have introgressed diseases resistance into several crops. Conventional breeding demands significant time and effort in field trials. Recent advances in manipulating resistance include protein and RNA-mediated resistance. RNA silencing 
is a process that can induce mRNA degradation or translation inhibition at the post-transcriptional level. It can also induce epigenetic modification at the transcriptional level [107].

Regardless of the method, informed deployment of major resistance traits will enable the production of crop varieties with effective resistance [108]. However, the development of resistant cultivars needs content evaluation as pathogens evolve. For example, the use of cultivars with different resistance genesto Leptosphaeriamaculans was suggested to lead to a different spectrum of virulent isolates in oilseed rape production [109111].

\section{Conclusion}

This work presented a review on root rot diseases that are a great threat to many crop systems around the world. Bacteria, virus, oomycetes and fungi are the main causal agents that can act as a primary pathogens or in combination with other pathogens in both field and greenhouse space. Bacterial stem and root rot also affects many crops and is common in storage, field and seedbeds. Viral root rots are even less common and were reported to be a problem in cassava production. Oomycetes and fungi are the most frequent yield reducers. Reported oomycetes are Aphanomyces spp., Pythium spp., and Phytophthora spp. Several fungi cause root rot, including, H. annosum, A. ostoyae and P. sulphurascens that have been reported as a problem for tree crops, as well as the broader host range pathogens Rhizoctonia spp., Fusarium spp.

Beneficial interactions such as legume-rhizobial and plantmycorrhizal relationships can improve the ability of a root system to withstand stress as well as provide a boost to the plant immune system. Some microbes can also inhibit other pathogens such as A. euteiches that is known to be suppressed by a vesicular-arbuscular mycorrhizal fungus. Knowledge of plantmicrobe and microbe-microbe interactions can also be the basis of biocontrol research.

Due to the high environmental influence, broad range of hosts, hidden underground symptoms and overwinter structures of many root rot pathogens, root rot disease control and management is complex and hard to achieve. Chemical treatment is generally only available as preventive seed treatment for some root rots or as a way to kill the green bridge between crops.

Therefore, the adoption of resistant or tolerant varieties is still the most promising tool to control root rot. As there is no complete resistance for major diseases such as Aphanomyces and Fusarium root rots due to the quantitative nature of this trait, breeding for this trait is very complex. Greenhouse assays and field screenings can be expensive and the use of markers becomes a great tool to identify sources of resistance. Reliable markers such as SNPs are still lacking to develop a research foundation that will provide an understanding of the genetic mechanisms underlying resistance as well as to be used in MAS.

\section{References}

1. Gonzalez M, Pujol M, Metraux JP, Gonzalez-Garcia V, Bolton MD, et al. (2011) Tobacco leaf spot and root rot caused by Rhizoctonia solani Kühn. Molecular plant pathology 12(3): 209-216.

2. Nzungize J, Gepts P, Buruchara R, Male A, Ragama P, et al. (2011) Introgression of Pythium root rot resistance gene into Rwandan susceptible common bean cultivars. African Journal of Plant Science 5(3): 193-200.

3. El Karkouri A, El Hassani FZ, El Mzibri M, Benlemlih M, El Hassouni $M$ (2010) Isolation and identification of an actinomycete strain with a biocontrol effect on the phytopathogenic Erwiniachrysanthemi 3937VIII responsible for soft rot disease. Annals of microbiology 60(2): 263-268.

4. Legg JP, Jeremiah SC, Obiero HM, Maruthi MN, et al. (2011) Comparing the regional epidemiology of the cassava mosaic and cassava brown streak virus pandemics in Africa. Virus Research 159 (2): 161-170.

5. Heffer V, Powelson ML, Johnson KB (2002) Oomycetes). The Plant Health Instructor.

6. Cleary M, Sturrock R, Hodge J (2011) Laminated Root Disease- Stand Establishment Decision Aid. Journal of Ecosystems and Management, North America.

7. Cui B, Dai YC, He S, Zhou, LW, et al. (2014) A Novel Phellinidium sp. Causes Laminated Root Rot on Qilian Juniper (Sabina przewalskii) in Northwest China. Plant disease 99(1): 39-43.

8. Harveson RM, Nielsen KA, Clay CC (2011) Determining optimal fungicide timing for Rhizoctonia root rot of sugar beet in Nebraska based on soil temperatures. Panhandle Research and Extension Center, p. 60.

9. Berg B, McClaugherty C (2014) Decomposition of Fine Root and Woody Litter. In: Plant Litter. Springer Berlin Heidelberg, Germany, pp. 171187.

10. Hamon C, Baranger A, Coyne CJ, Mcgee RJ, Le Goff IL, et al. (2011) New consistent QTL in pea associated with partial resistance to Aphanomyces euteiches in multiple field and controlled environments from France and the United States. Theor Appl Genet 123(2): 261-281.

11. Liberato JR, Sanhueza RMV, Miles AK, Horlock C (2011) White root rot (Rosellinia necatrix). 2 Mar 2014.

12. Jung YS, Kim YT, Yoo SJ, Kim HG (1999) Mycological characteristics of Fusarium solani f. sp. Pisi isolated from pea, ginseng and soybean in Korea. Plant Pathology Journal 15(1): 44-47.

13. Dalman K, Olson A, Stenlid J (2010) Evolutionary history of the conifer root rot fungus Heterobasidion annosum sensu lato. Molecular Ecology 19(22): 4979-4993.

14. Abdel-Monaim MF, Abo-Elyousr KAM (2012) Effect of preceding and intercropping crops on suppression of lentil damping-off and root rot disease in New Valley-Egypt. Crop Protection 32: 41-46.

15. Charkowsky AO (2006) The Soft Rot Erwinia. In: Gnanamanickam S (Ed.), Plant-Associated Bacteria. Dordrecht, Springer, The Netherlands 3: 423-505.

16. Huang JH, Ann PJ, Chiu YH, Tsai JN (2012) First report of Phytophthoracambivora causing leaf and stem blight and root rot on taiwan cherry (Prunus campanulata) in Taiwan- Plant Disease. 96(7): 1065.

17. Ames T (2014) Sweet Potato Diseases.

18. Akamatsu HO, Grunwald NJ, Chilvers MI, Porter LD, Peever LT (2007) Development of codominant simple sequence repeat, single nucleotide polymorphism and sequence characterized amplified region markers for the pea root rot pathogen, Aphanomyc eseuteiches. J Microbiol Met 71(1): 82-86 
19. Smith D, Watson Q (2014) Aphanomyces root rot management in Alfalfa. UW-Madison Plant Pathology.

20. Richard C, Beghdadi A, Martin JG (1991) Aphanomyces euteiches, a novel root pathogen to alfalfa in Québec. Plant Disease 75(3): 319.

21. van Leur JAG, Southwell R, Mackie J (2008) Aphanomyces root rot on faba bean in northern NSW. Australasian Plant Disease Notes 3(1): 8-9.

22. Pfender WF, Malvick DK, Pfleger FL, CR Grau (2011) Aphanomyces root rot. In: Kraft JM, Pfleger FL (Eds.), Compendium of pea diseases and pests. $\left(2^{\text {nd }}\right.$ edn), APS Press, USA, pp. 9-13.

23. Conner RL, Chang KF, Hwang SF, Warkentin TD, McRae KB (2013) Assessment of tolerance for reducing yield losses in field pea caused by Aphanomyces root rot. Can J Plant Sci 93: 473-482.

24. Kraft JM, Pfleger FL (2001) Compendium of pea diseases and pests, second edition. APS Press, Saint Paul, The American Phytopathological Society, USA.

25. Vandemark GJ, Grünwald NJ (2005) Use of real-time PCR to examine the relationship between disease severity in pea and Aphanomyces euteiches DNA content in roots. European Journal of Plant Pathology 111(4): 309-316.

26. Dick MW (2001) The peronosporomycetes. In: McLaughlin DJ, McLaughlin EG, Lemke PA, (Eds.), The Mycota VII. Part A. Systematics and Evolution. Springer-Verlag, Berlin, Germany, pp. 39-72.

27. Paulitz TC, Adams K (2003) Composition and Distribution of Pythium communities in wheat fields in eastern Washington state. Phytopathology 93(7): 867-73.

28. Chao L, Long Y, Yong X, Li W, Yu ZT, et al. (2012) First report on root rot of tobacco caused by Pythium diclinum. Journal of Yunnan Agricultural University 27(6): 905-909.

29. Elmer WH, Gent MPN, McAvoy RJ (2012) Partial saturation under ebb and flow irrigation suppresses Pythium root rot of ornamentals. Crop Protection 33: 29-33.

30. Zhang H, Franken P (2014) Comparison of systemic and local interactions between the arbuscular mycorrhizal fungus Funneliformis mosseae and the root pathogen Aphanomy ceseuteiches in Medicago truncatula. Mycorrhiza 24(6): 419-430.

31. Petkowski JE, De Boer RF, Norng S, Thomson F, Minchinton EJ (2013) Pythium species associated with root rot complex in winter-grown parsnip and parsley crops in south eastern Australia. Australasian Plant Pathology 42(4): 403-411.

32. Dissanayake N, Hoy JW, Griffin JL (1998) Herbicide Effects on Sugarcane Growth, Pythium Root Rot, and Pythium arrhenomanes. Phytopathology 88(6): 530-535.

33. Mavrodi OV, Walter N, Elateek S, Taylor CG, Okubara PA (2012) Suppression of Rhizoctonia and Pythium root rot of wheat by new strains of Pseudomonas. Biological Control 62(2): 93-102.

34. Heyman F, Blair JE, Persson L, Wikstrom M (2013) Root rot of pea and faba bean in southern Sweden caused by Phytophthorapisi sp. nov. Plant Disease 97: 461-471.

35. Henricot B, Sierra PA, T Jung (2014) Phytophthorapa chypleura sp. nov., a new species causing root rot of Aucuba japonica and other ornamentals in the United Kingdom. Plant Pathology, doi: 10.1111/ ppa.12194.

36. Jia RZ, Paidi M, Lim S, Cho IK, Li QX, et al. (2012) Comparative protein expression of two papaya cultivars showing a differential response to the root-rot pathogen Phytophthora palmivora. Journal of Plant Pathology 94(3): 571.

37. Graham J, Hackett CA, Smith K, Woodhead M, MacKenzie K, et al. (2011) Towards an understanding of the nature of resistance to Phytophthora root rot in red raspberry. Theoretical and Applied Genetics 123: 585601.

38. Moore K, Ryley M, Hobson K, Harden S, Martin W, et al. (2013) Response of chickpea genotype to Phytophthora root rot, PRR (Phytophthora medicaginis). In: Pulse Breeding Australia Inaugural Conference (PBA 2013): Expanding Horizons. Adelaide, Australia.

39. Du W, Zhao X, Raju T, Davies P, Trethowan R (2013) Studies on the resistance of Australian chickpea (Cicer arietinum L.) to Phytophthora root rot disease. Australian Journal of Crop Science 7(6): 794-800.

40. Truong HTH, Kim KT, Kim DW, Kim S, et al. (2012) Identification of isolate-specific resistance QTLs to Phytophthora root rot using an intraspecific recombinant inbred line population of pepper (Capsicum annuum). Plant Pathol 61(1): 48-56.

41.Zhang W, Dick WA, Hoitink HA (1996) Compost induced systemic acquired resistance in cucumber to Pythium root rot and anthracnose. Phytopathology 86: 1066-1070.

42. Orlikowski LB, Ptaszek M, Rodziewicz A, Nechwatal J, Thinggaard K, et al. (2011) Phytophthora root and collar rot of mature Fraxinus excelsior in forest stands in Poland and Denmark. Forest Pathology 41: 510-519.

43. KurbetliI, Orzan S (2013) Occurrence of Phytophthora root and stem rot of kiwifruit in Turkey. Journal of Phytopathology 161(11-12): 887889.

44. Menge JA, Douhan GW, McKee B, Pond E, Bender GS, et al. (2012) Three New Avocado Rootstock Cultivars Tolerant to Phytophthora Root Rot: 'Zentmyer', 'Uzi', and 'Steddom'. Hort Science 47(8): 1191-1194.

45. Napierała-Filipiak A, Filipiak M (2011) Effects of Scots pine (Pinussylvestris) natural selection in old foci of Heterobasidion annosum root rot. Dendrobiology 66: 63-69.

46. Gori Y, Cherubini P, Camin F, La Porta N (2013) Fungal root pathogen (Heterobasidion parviporum) increases drought stress in Norway spruce stand at low elevation in the Alps. Eur J Forest Res 132: 607619.

47. Sinclair WA, Lyon (2005) Diseases of trees and shrubs. ( $2^{\text {nd }}$ edn), Ithaca, Comstock Pub, Cornell University Press, New York, USA.

48. Coetzee MPA, Wingfield BD, Harrington TC, Steimel J, Coutinho TA, et al. (2001) The root rot fungus Armillariamellea introduced into South Africa by early Dutch settlers. Molecular Ecology 10(2): 387-396.

49. Bakys R, Vasiliauskas A, Ihrmark K, Stenlid J, Menkis A, et al. (2010) Root rot, associated fungi and their impact on health condition of declining Fraxinus excelsior stands in Lithuania. Scand J For Res 26(2): 128-135.

50. Aguin-Casal 0, Sainz-Oses MJ, Mansilla-Vazquez JP (2014) Armillaria species infesting vineyards in northwestern Spain. European Journal of Plant Pathology 110(7): 683-687.

51. Pellegrini A, Corneo PE, Camin F, Ziller L, Tosi S, et al. (2013) Isotope ratio mass spectrometry identifies soil microbial biocontrol agents having trophic relations with the plant pathogen Armillaria mellea. Applied Soil Ecology 64: 142-151.

52. Thomidis T, Exadaktylou E (2012) Effectiveness of cyproconazole to control Armillaria root rot of apple, walnut and kiwifruit Crop Protection 36: 49-51.

53. Miller RE, Harrington TB, Thies WG, Madsen J (2006) Laminated root rot in a western Washington plantation: 8-year mortality and growth of Douglas-fir as related to infected stumps, tree density, and fertilization. US Department of Agriculture, Forest Service, Pacific Northwest Research Station, USA, p. 37.

54. Kondo H, Kanematsu S, Suzuki N (2013) Viruses of the white root rot fungus, Rosellinia necatrix. Adv Virus Res 86: 177-214. 
55. Bhat ZA, Sheikh FA, Mubarak T, Bhat JA, Zargar MA, et al. (2012) On farm testing and popularization of integrated management module of apple root rot under high altitude temperate conditions. Journal of Krishi Vigyan 1: 54-57.

56. Daes J, Hua GKH, De Maeyer K, Pannecoucque J, Forrez I, et al. (2011) Biological control of Rhizoctonia root rot on bean by phenazine- and cyclic lipopeptide-producing Pseudomonas CMR12a. Phytopathology 101(8): 996-1004.

57. Hewavitharana S, Mazzola M (2013) Carbon source-dependent efficacy of anaerobic soil disinfestation (ASD) in suppression of Rhizoctonia root rot of apple. Phytopathology 103: S2.60.

58. Haralson JC, Brannen PM, NeSmith DS, Scherm H (2013) Chemical control of Cylindrocladium and Rhizoctonia root rots in blueberry propagation. Crop Protection 44: 1-5.

59. Solanki MK, Singh N, Singh RK, Singh P, et al. (2011) Plant defense activation and management of tomato root rot by a chitin-fortified Trichoderma/Hypocrea formulation. Phytoparasitica 39(5): 471.

60. Singh LR, Kumar B, Shulkla A (2014) Management of Rhizoctonia root rot of pea (Pisumsativum L.) by integrated biological and chemical approach. International Journal of Agricultural Sciences 10(1): 108114.

61. Schroeder KL, Paulitz TC (2012) First report of root rot caused by Rhizoctonia solani AG-10 on canola in Washington State Plant Disease 96(4): 584.

62. Ajayi 00, Paulitz TC, Campbell K, Murphy KM, Ullrich SE (2013) Identification of resistance to Rhizoctonia root rot in mutant and wild barley (Hordeum vulgare subsp. spontaneum). Phytopathology 103: S2 S3.

63. Marimuthu S, Ramamoorthy V, Samiyappan R, Subbian P (2013) Intercropping system with combined application of Azospirillum and Pseudomonas fluorescens reduces root rot incidence caused by Rhizoctonia bataticola and increases seed cotton yield. Journal of Phytopathology 161: 405-411.

64. Kamfwa K, Mwala M, Okori P, Gibson P, Mukankusi C (2013) Identification of QTL for fusarium root rot resistance in common bean. Journal of Crop Improvement 27(4): 406-418.

65. Hegde N, Baer D, Asija P, Shetty K, Rasmussen JB, Goswami RS (2012) Evaluating seed treatments for their ability to control Fusarium root rot in legumes. Phytopathology 102(7): 52-52.

66. Díaz-Arias MM, Munkvold GP, Leandro LF (2011) First report of Fusarium proliferatum causing root rot on soybean (Glycine max) in the United States. Plant Disease 95(10): 1316.

67. Akhtar MS, Azam T (2014) Effects of PGPR and antagonistic fungi on the growth, enzyme activity and Fusarium root-rot of pea. Archives of Phytopathology and Plant Protection 47(2): 138-148.

68. Casasnovas F, Fantini EN, Palazzini JM, Giaj-Merlera G, Chulze SN, et al. (2013) Development of amplified fragment length polymorphism (AFLP)-derived specific primer for the detection of Fusarium solania etiological agent of peanut brown root rot. Journal of Applied Microbiology. 114(6): 1782-1792.

69. Wang RY, Gao B, Li XH, Ma J, Chen SL (2014) First report of Fusarium solani causing fusarium root rot and stem canker on storage roots of sweet potato in China. Plant Disease 98(1): 160-160.

70. Barros JA, Medeiros EV, Notaro KA, Moraes WS, Silva JM, et al. (2014) Different cover promote sandy soil suppressiveness to root rot disease of cassava caused by Fusarium solani. African Journal of Microbiology Research 8(10):967-973.

71. Scherm B, Balmas V, Spanu F, Pani G, Delogu G, et al. (2013) Fusarium culmorum: causal agent of foot and root rot and head blight on wheat.
Mol Plant Pathol 14(4): 323-341.

72. Lops F, Cibelli F, Raimondo ML, Carlucci A (2013) First report of stem wilt and root rot of Schlumbergera truncata caused by Fusarium oxysporum f. sp. Opuntiarum in Southern Italy. Plant Disease 97(6): 846.

73. Cohen R, Orgil G, Burger Y, Saar U, Elkabetz M, et al. (2014) Differences in the responses of melon accessions to fusarium root and stem rot and their colonization by Fusarium oxysporumf. sp. radicis-cucumerinum. Plant Pathology 64(3): 655-663.

74. Mishra RK, Sharma P, Srivastava DK (2012) First Report of White DG (1999) Compendium of corn diseases. ( $3^{\text {rd }}$ edn), American Phytopathological Society Press, USA.

75. causing pink root rot of onion in India. Vegetos- An International Journal of Plant Research 25(2): 306-307.

76. Sweets LE, Wright S (2008) Corn Diseases - Integrated Pest Management PM 1001.

77. Wunsch, MJ, Bergstrom GC (2011) Genetic and morphological evidence that Phoma sclerotioides, causal agent of brown root rot of alfalfa, is composed of a species complex. Phytopathology 101(5): 594-610.

78. Almario J, Muller D, Défago G, Oënne-Loccoz YM (2014) Rhizosphere ecology and phytoprotection in soils naturally suppressive to Thielaviopsis black root rot of tobacco. Environmental Microbiology 16(7): 1949-1960.

79. Elsayed FAA, Abeer H, Ali HB, AL-Huqail A (2011) First report of black root rot disease (Thielaviopsis basicola) of carrot in Saudi Arabia. African Journal of Microbiology Research 5(18): 2867-2869.

80. Ma J, Jaraba J, Kirkpatrick TL, Rothrock CS (2011) Effects of Meloidogyne incognita and Thielaviopsis basicola on cotton growth and root Morphology Phytopathology 104(5): 507-512.

81. Monfort WS, Carroll AG, Emerson MJ, Fortner J (2010) First report of black root rot caused by Thielaviopsis basicola on soybean (Glycine max) in Arkansas. Plant Disease 94(9): 1168.

82. Zaman N, Ahmed S (2012) Survey of root rot of groundnut in rainfed areas of Punjab, Pakistan. African Journal of Biotechnology 11(21): 4791-4794.

83. Manjunatha SV, Naik MK, Khan MR, Goswami RS (2013) Evaluation of bio-control agents for management of dry root rot of chickpea caused by Macrophomina phaseolina. Crop Protection 45: 147-150.

84. Louws F (2012) Black Root Rot of Strawberry. NC Cooperative Extension Factsheets, USA.

85. Xue AG (2002) Biological control of pathogens causing root rot complex in field pea using Clonostachys rosea strain ACM941. The American Phytopathological Society 93(3): 229-235.

86. Hosseini S, Karlsson M, Jensen DF, Heyman F (2011) Quantification of Phytophthorapisi DNA and RNA transcripts during in planta infection of pea. European journal of plant pathology 132(3): 455-468.

87. Xu L, Ravnskov S, Larsen J, Nilsson RH, Nicolaisen M (2012) Soil fungal community structure along a soil health gradient in pea fields examined using deep amplicon sequencing. Soil Biology and Biochemistry 46: 2632.

88. Abawi GS, TL Widmer (2000) Impact of soil health management practices on soilborne pathogens, nematodes and root diseases of vegetable crops. Applied Soil Ecology 15(1): 37-47.

89. Babiker EM, Hulbert SH, Schroeder KL, Paulitz TC (2011) Optimum timing of preplant applications of glyphosate to manage Rhizoctonia root rot in barley. Plant Disease 95(3): 304-310.

90. Dubey SC, Bhavani R, Singh B (2011) Integration of soil application and 
seed treatment formulations of Trichoderma species for management of wet root rot of mungbean caused by Rhizoctonia solani. Pest management science 67(9): 1163-1168.

91. Serrano MS, De Vita P, Fernández-Rebollo P, Hernández MES (2012) Calcium fertilizers induce soil suppressiveness to Phytophthora cinnamomi root rot of Quercus ilex. European journal of plant pathology 132(2): 271-279.

92. Kou Y, Wang S (2010) Broad-spectrum and durability: understanding of quantitative disease resistance. Current opinion in plant biology 13(2): 181-185.

93. Young ND (1996) QTL mapping and quantitative disease resistance in plants. Annual review of phytopathology 34: 479-501.

94. Ashraf M, Akram NA, Foolad MR (2012) Marker-assisted selection in plant breeding for salinity tolerance. Plant Salt Tolerance Humana Press 913: 305-333.

95. Shao ZQ, Zhang YM, Hang YY, Xue JY, Zhou GC, et al. (2014) Longterm evolution of nucleotide-binding site-leucine-rich repeat genes understanding gained from and beyond the legume family. Plant physiology 166(1): 217-234.

96. Carrillo E, Satovic Z, Aubert G, Boucherot K, Rubiales D, et al. (2014) Identification of quantitative trait loci and candidate genes for specific cellular resistance responses against Didymella pinodes in pea. Plant cell reports 33(7): 1-13

97. Winter PS, Bowman CE, Villani PJ, Dolan TE, Hauck NR (2013) Systemic acquired resistance in moss: further evidence for conserved defense mechanisms in plants. PloS one 9(7): e101880.

98. Boyd LA, Ridout C, O'Sullivan DM, Leach JE, H Leung (2013) Plantpathogen interactions: disease resistance in modern agriculture. Trends Genet 29(4): 233-240.

99. Foroud NA, Chatterton S, Reid LM, Turkington TK, Tittlemier SA, et al. (2014) Fusarium Diseases of Canadian Grain Crops: Impact and Disease Management Strategies. In: future challenges in crop protection against fungal pathogens. Springer, New York, USA, pp. 267-316.

100. Gardiner DM, Stephens AE, Munn AL, Manners JM (2013) An ABC pleiotropic drug resistance transporter of Fusarium graminearum with a role in crown and root diseases of wheat. FEMS Microbiol Lett 348(1): 36-45.
101. González-Sánchez MA, Cazorla FM, Ramos C, de Vicente A, PérezJiménez RM (2004) Studies of soil and rhizosphera bacteria to improve biocontrol of avocado white root rot caused by Rosellinia necatrix. Management of plant diseases an arthropod pests by BCAs and their integration in agricultural 27: 169-172.

102. Hanson LE, Mo T, Goodwill TR (2012) Variability in Phoma species affecting sugar beet. APS Meeting PS 69P.

103. Hossain S, Bergkvist G, Berglund K, Mårtensson A, Persson P (2012) Aphanomyces pea root rot disease and control with special reference to impact of Brassicaceae cover crops. Acta Agriculturae Scandinavica, Section B-Soil \& Plant Science 62(6): 477-487.

104. Huang LF, Fang BP, Luo ZX, Chen JY, Zhang XJ, et al. (2010) First report of bacterial stem and root rot of sweet potato caused by a Dickeya sp. (Erwinia chrysanthemi) in China. Plant Disease 94(12): 1503.

105. Luna E, Bruce TJ, Roberts MR, Flors V, Ton J (2012) Next-generation systemic acquired resistance. Plant Physiology 158(2): 844-853.

106. Malvick D, Babadoost M (2002) Report on Plant Disease. RPD No. 911 Apr. 2002. Department of Crop Sciencesuniversity of Illinois at Urbana-Champaign.

107. Nandris D, Chadoeuf J, Pierrat JC, Joannes H, Geiger JP, et al. (1996) Modelling rubber-tree root diseases, simulations of various inoculum rates and methods of control. European Journal of Forest Pathology 26: $25-44$

108. Nedaienia R, Fassihiani A (2011) Host range and distribution of Pectobacterium betavasculorum, the causal agent of bacterial vascular necrosis and root rot of sugar beet in Fars province in Iran. J Plant Path 47(2): 47-48.

109. Sugawara K, Tsukiboshi T, Kikawada T, Tamaki H, Okabe I, et al (2011) Pythium root rot of corn in Japan; unique symptom climbs up the mature stem, and possible drift of the major species in causal Pythium flora. Phytopathology 101(6): S173.

110. Vandemark GJ, Ariss JJ, Hughes TJ (2009) Real-time PCR suggests that Aphanomyces euteiches is associated with reduced amounts of phytophthora medicaginis in alfalfa that is co-inoculated with both pathogens. Journal of Phytopathology 158(2): 117-124.

111. Zhang Z, Hao J, Yuan J, Song Q, Hyten DL, et al. (2014) Phytophthora root rot resistance in soybean E00003. Crop Science 54(2): 492-499.

\section{Your next submission with Juniper Publishers will reach you the below assets}

- Quality Editorial service

- Swift Peer Review

- Reprints availability

- E-prints Service

- Manuscript Podcast for convenient understanding

- Global attainment for your research

- Manuscript accessibility in different formats

(Pdf, E-pub, Full Text, Audio)

- Unceasing customer service

Track the below URL for one-step submission https://juniperpublishers.com/online-submission.php 